\title{
Explaining the Reasons for the Deteriorating Sino- American Relations Before and After the Outbreak of COVID-19 Pandemic
}

\author{
Jingyi Chen
}

\author{
Valley Christian Schools, Cerritos, California, United States \\ Email: alice.jingyi.chen@qq.com
}

\begin{abstract}
In recent years, there have been lots of challenges and difficulties for Sino-American relations, which many scholars and the international society have paid attention to. During the COVID-19, the two countries did not cooperate in fighting against the pandemic as the international community expects, and the Sino-American relations even got worse. In order to figure out the reasons for the Sino-American deteriorating relations, people should not only analyze the specific conflicts but also investigate the deep reasons behind the superficial explanations the two governments provided for their policies relating to each other. This paper tries to answer the question above from international and domestic levels. From the international version, the anarchy of the international society, Thucydides' Trap and the power transition theory can help understand why China and the United States have increased conflicts in the past years. From the domestic perspective, the differences in ideology and political systems, the public emotions and nationalism are the possible reasons that China and the United States have few cooperation during the pandemic.
\end{abstract}

Keywords: China, United States, COVID-19, International Cooperation.

\section{INTRODUCTION}

In the past decades, the United States remains the most powerful country in the world and exerts significant impacts on other countries, including China. After the rupture of the Sino-Soviet relation in the 1960s, although China and the United States established diplomatic relations in 1979, they held complicated views on each other. During the past decades, China has regarded the U.S. as a threat to its ideology and tried to resist the U.S. influence on its domestic politics and foreign policies. Concerns over China's rise also exist within the U.S. The Obama administration put forward the strategy of "rebalancing" to the Asia-Pacific in 2012, expecting to furtherly strengthen the presence of the U.S. in this region and to play a more significant role in China's relations with neighbouring countries [1]. In recent years, it seems that Sino-American relation has been deteriorated, especially during Donald Trump's administration.

At the political and military level, the United States frequently engaged in the issues in the Asia-Pacific area, which, from China's perspective, is targeting China and inciting China's relations with the nearby countries. The policies of the U.S. in the South China Sea (SCS) disputes offer an example. The disputes among China, Vietnam, the Philippines, Malaysia and Brunei have occurred for a long period, and the U.S. had not directly intervened in the disputes before 2010. However, in July 2010, at the annual foreign ministers' meeting of the ASEAN Regional Forum (ARF) in Hanoi, the then-US Secretary of State Hillary Clinton declared that the U.S. had important interests in the South China sea, so it offered to help foster multilateral negotiations as a U.S. leading diplomatic priority to guarantee the freedom of navigation, open access to Asia's maritime commons and respect for international law [2], marking the first time the United States getting a deep involvement in the SCS disputes. The U.S.'s involvements include strengthening its military presence in SCS, enhancing its security cooperation with the Philippines and Vietnam, and supporting Manila and Hanoi in their resistance to Beijing on the issue [1]. Against this background, the SCS disputes become a flashpoint that may cause conflicts between China and the U.S.

At the economic level, during the Obama's administration, the Trans-Pacific Partnership (TPP) Agreement has been utilized as a tool to increase America's economic power in the Pacific region, which, 
in China's view, has aimed at weakening China's significant economic role among the TPP members [1]. In response, China pursued its own Free Trade Agreements, like Regional Comprehensive Economic Partnership (RCEP), to enhance its economic tie with other Asia-Pacific countries. The Sino-US trade war that lasted from 2018 to the present represents the strained relationship between China and the U.S. The Trump administration declared that it was necessary to "fight back in the trade war" due to China's behavior of "stealing technology and trade secrets, and unfairly treating U.S. companies who wanted to do business there" [3]. On June 15, 2018, the then-President Donald Trump made an announcement that the U.S. will add new tariffs on Chinese products worth $\$ 34$ bn, starting from July 6, 2018 [4]. In response, China also added tariffs worth $\$ 34$ bn on U.S. agricultural and industrial products [5]. From that time, the United States and China got more tensions and conflicts, and the trade conflicts have not been resolved despite that Joe Biden has been the new President for more than six months.

The negative diplomatic relationship has affected nonofficial relations and communication. According to the report of China's Xinhua News on June 13, 2019, the U.S. had been restricting the visas of Chinese students who planned to study there. Some of the students, typically science, engineering, technology and math students, were facing a more extended examination process, shortened time of visa validation, and higher refusal rate [6]. On July 6, 2021, Zhao Lijian, the spokesperson of the Ministry of Foreign Affairs of China, stated that more than 500 Chinese students were being denied U.S. visas, and this seriously harmed Chinese international students' interests and undermined the cooperation and cultural exchanges between the two countries. Therefore, China urged the U.S. to stop the unprovoked suppression of Chinese students and reconsider their applications for U.S. visas [7].

As the world's greatest superpower and the world's fastest growing state, the U.S. and China are not unable to cooperate in scientific research and information sharing under the framework provided by the World Health Organization (WHO). Taking Sino-American interactions during the COVID-19 pandemic as another example, China and the United States experienced difficulties cooperating with each other to fight against the pandemic. By investigating the international and domestic factors, respectively, this article will investigate why the two states have difficulties maintaining a friendly relationship and cooperating with each other. The first part of this essay will analyse the "structural" reasons that explain the deterioration of the Sino-US relationship. Following that, the second part will focus on the domestic factors that impede the two countries' cooperation in combating the virus.

\section{2. "STRUCTURAL" REASONS FOR THE DETERIORATION OF THE SINO-US RELATIONSHIP}

From the international perspective, the status of anarchy in the international society helps to explain why disagreements between China and the U.S. could hardly be resolved. When China and the U.S. have conflicts in some issues, there is no supranational organization to manage their relationship. The United Nations have limited administrative power, and its budgets mainly come from U.S., Japan, China and other major powers. It is not sufficiently effective to manage the conflicts between U.S. and China. For instance, during COVID-19, although the WHO provided a coordinator for international communication and medical cooperation, it did not have any supranational authority to force China and U.S. to cooperate. Moreover, Donald Trump accused that the WHO is virtually controlled by China [8]. Consequently, the debates on the origin of COVID-19, the distinct policies on social distancing, and the economic loss due to the pandemic have all made the Sino-US relations even worse.

Furthermore, Thucydides' Trap, as stated by Graham Allison and other scholars, can be used as a useful framework to understand the possible reasons for conflicts between China and U.S. [9] In history, when a state is rising and challenges the power of an existing superpower, war often occurs. Many newly rising powers and the ruling powers fell into conflicts, like Athens \& Sparta in the fifth century BCE, Germany \& the U.K. in the 1910s. Thucydides believed the fundamental reason that the competition between Athens and Sparta led to a devastating war is "the structural stress between a rising and a ruling power". Interests, fear and honor made the relation between two states got more tensions in competition. Consequently, Sparta and Athens fell into "successive standoffs", and the most passionate voices in the two states took the lead and vehemently challenged the leaders who tried to maintain peace.

China's rapid growth is challenging United States' position as a superpower. As Allison states, "When a rising power threatens to displace a ruling power, alarm bells should sound: danger ahead. China and the United States are currently on a collision course for war-unless both parties take difficult and painful actions to avert it." Although Allison believes that China and the United States are also facing the danger of getting into a war, he thinks war is not inevitable. He suggests that the U.S. leaders need to get a deeper understanding of the root causes of Sino-US conflicts, know China's core interests, and make long-term strategy. He also points out that both China and the U.S. should "make domestic challenges central", which means that the most critical challenges for them are finding the failures of their political system [9]. 
Furthermore, the power transition theory can be used to explain Sino-American conflicts. The theory states that a rapidly growing state will challenge the current dominant state to gain more power and higher status [10]. China, in recent years, is rapidly enhancing its technology, economics and international influence. As Figure 1 shows, China keeps having a relatively high GDP growth comparing to the U.S. In 2020, although COVID-19 strikes the world economy, China still has a $2.3 \%$ annual GDP growth. As Figure 2 demonstrates, in the recent ten years, the military expenditure of the U.S. in percent of GDP decreased, while China's was relatively stable. When China's strength grows, its international status and influential power are also rising. Against this background, China desires to obtain respect from the world as a great country and receive more interests that it thinks it deserves, while the United States wants to maintain its status as the superpower in the world. Thus, it will cause friction between the two states.

Annual GDP growth (US vs China)



Source: World Bank (https://data.worldbank.org/)

Figure 1 China keeps a significantly high GDP growth rate comparing to that of the U.S. since 1980.
Military Expenditure (\% of GDP)



Source: World Bank (https://data.worldbank.org/)

Figure 2 United States' spending on military expenditure has a lower proportion in its GDP comparing to the past, while China's proportion in its GDP is relatively stable.

\section{DOMESTIC REASONS FOR LACK OF COOPERATION IN COMBATING THE VIRUS}

\subsection{Ideological Conflicts}

The ideological difference is a complex reason for the conflict. John J. Mearsheimer states that the ideological differences "do not affect the relationship between the two countries in profound ways". For one thing, China is deeply engaged in the world economy, and the economic interdependence, as believed by many people, is significant for maintaining peace. For another, China does not desire to spread its ideological model to the rest of the world. Therefore, although the ideological differences can result in some conflicts, it is not likely to be a direct cause of the recent conflicts [11].

However, China and the U.S. indeed have distinct ideas about the social order and ruling a country, and those differences are reflected in their policies. In recent years, ideology conflicts have been increasingly significant between the two countries. The U.S. Strategic Approach Towards China, published by the Trump administration in 2020, emphasized that the Chinese Communist Party's (CCP) promotion of its value proposition "challenges the bedrock American belief in the unalienable right of every person to life, liberty, and the pursuit of happiness" [12]. China's policies in containing the COVID-19, like mandatory quarantining and locking down the city Wuhan, are criticized by the U.S. media initially. At the early stage of the pandemic, the U.S. media showed the scene of the Chinese government monitoring its citizens by using drone, which deepened American audience's impression of China's 
authoritarianism and strong controls over its people [13]. Also, the then-Secretary of State Pompeo criticized China for concealing the information of COVID-19. In corresponding, China stated that the U.S. has the most advanced medical technology but works poorly in controlling the spread of the pandemic. China also criticized the United States of regarding the political interests first, ignoring of seriousness of the pandemic and trying to blame China [14].

\subsection{The United States}

The U.S. federal government's power is limited because of many factors, like capital, citizens' opinions, concern on human freedom when making socialdistancing policies, central-local relationship, so it was hard for the U.S. to efficiently control the spread of the virus during the beginning of the pandemic. The government and a large number of citizens believed China should take responsibility for the damage caused by the pandemic. The Trump administration had a relatively negative attitude toward the virus. When the spread of the pandemic got severe, they started to criticize China for the insufficient share of information and control of the spread. In addition to this, the high economic stress and fear caused by the pandemic made citizens' anti-China emotions grow considerably in the U.S. The government and the public both distrusted China, so the possibility to cooperate with China on fighting against the pandemic became very low.

What is more, there are some debates on the origin of COVID-19. At first, China declared that the virus probably originated from Wuhan, Hubei, China. Later, when the pandemic started to spread over the whole United States, the then-president Donald Trump called the virus "Chinese Virus" and claimed that the reason he called this way is "it comes from China", which created tension in Sino-US foreign relations. Chinese experts criticized Trump's use of this phrase, which, they stated, would cause xenophobia. In fact, many Asian Americans indeed had experienced racial slurs and physical abuse [15]. As an example, on March 18, 2020, a Chinese woman named Jiayang Fan told her story of getting verbal insult from a stranger during the pandemic on Twitter. From her description, the man who did not seem mentally ill or drunk kept verbally attacking Chinese [16]

\subsection{China}

Because of China's special political system, the government is able to gather the resources of the whole country, including medical equipment, human resources, and fund to treat the infected people and control the spread of the pandemic with relatively high efficiency, despite that China's reaction toward the first break-out of the pandemic was also criticized for being not quick enough by the public at the early stage of the pandemic.
Therefore, it was not that urgent for China to receive assistance from or cooperate with the U.S. to contain the spread of the virus within China.

At the same time, Chinese people's nationalism is growing. The country's media and education encourage people to feel proud of their own culture and political system, and people tend to believe that China deserves greater power and higher status in the international society. As a result, a great number of people expect their government to have a stronger attitude on foreign affairs, and they frequently state their opinions and impact the mainstream opinion on the public social platform. Consequently, Chinese people will have a less positive attitude when thinking about the Sino-American relationship.

\section{CONCLUSION}

It is evident that the Sino-US competition is getting more intense in recent years. China has developed at high speed these years. For instance, China's GDP growth keeps much higher than that of the U.S., and China is increasing the military expenditure with the growth of its economy. Using Thucydides' Trap and the power transition theory as frameworks to explain the conflicts, China's rapid growth and increased involvement in managing global issues are challenging the U.S. as the only superpower in the world, which causes the U.S. to take actions in order to control the situation. Furthermore, as China's national strength and influence are growing, it actively challenges the existing leading power, the U.S., to gain more power which it believes it deserves. Under this situation, the status of anarchy of the international society causes the Sino-US relation to getting worse. There is no supernational power to supervise and adjust China's and U.S.'s foreign policies toward each other.

From the domestic version, the ideological differences reflected on China's and U.S.'s political system and social order also cause tension between the two countries. The criticism of the two countries on each other of the other side's policies and performance during the COVID-19 show the conflicts originated mainly from ideological differences and the desire to show its people the advantage of its political system. The U.S. government did not have a satisfying performance in the first outbreak of COVID-19 under Trump's administration, and they accused China of hiding the information and letting the virus spread. American citizens also became more negative regarding China because of their material and spiritual loss due to the pandemic and the idea that China caused it. China's authoritarian system makes it have a relatively satisfying work on fighting against the pandemic, so China's government neither desires nor needs to receive medical assistance from the U.S. Moreover, the Chinese government promotes citizens to trust its political system and be proud of its country in medias and education, and 
the nationalism voices in China are growing and impacting other Chinese. Therefore, the Sino-US cooperation in fighting against the virus did not occur as much as the international community wishes. Furthermore, the tension between the two countries will probably grow stronger in the future. The complicated situations and dramatic events that impact the SinoAmerican relationship will be meaningful for more academic analysis and debates.

\section{REFERENCES}

[1] Wu, Xinbo. "Cooperation, Competition and Shaping the Outlook: The United States and China's Neighbourhood Diplomacy." International Affairs, vol. 92, no. 4, 20 June 2016, pp. 849-867, 10.1111/1468-2346.12651. Accessed 11 Dec. 2019.

[2] Zhao, Suisheng. "A New Model of Big Power Relations? China-US Strategic Rivalry and Balance of Power in the Asia-Pacific." Journal of Contemporary China, vol. 24, no. 93, 8 Oct. 2014, pp. 377-397, 10.1080/10670564.2014.953808.

[3] Jethro Mullen. "China: The US Has Started 'the Biggest Trade War' in History.” CNNMoney, 6 July 2018, money.cnn.com/2018/07/06/news/economy/u

s-china-trade-war-tariffs/index.html. Accessed 15 July 2021.

[4] Palumbo, Daniele. "Charting the US-China Trade Battle." BBC News, 6 July 2018, www.bbc.com/news/business-44728166. Accessed 15 July 2021.

[5] Tan, Weizhen. "Trade War Begins: US and China Exchange \$34 Billion in Tariffs." CNBC, 6 July 2018, www.cnbc.com/2018/07/06/trade-warworries-us-china-tariffs-to-kick-in-on-friday.html.

[6] Xinhua News Agency Reporter. "Summary: Chinese Students Are Restricted from Getting the U.S. Visa, the American Education Circles Express Worries." www.gov.cn, 13 June 2019, www.gov.cn/xinwen/201906/13/content_5399895.htm. Accessed 6 July 2021.

[7] Xinhua News Agency Reporter. "Zhao Lijian Criticizes the US of 'Reversing History.", www.xinhuanet.com, 6 July 2021, www.xinhuanet.com/world/202107/06/c_1127627944.htm. Accessed 24 July 2021.

[8] Neuman, Scott. "In U.N. Speech, Trump Blasts China and WHO, Blaming Them for Spread of COVID-19." NPR.org, 22 Sept. 2020, www.npr.org/sections/coronavirus-liveupdates/2020/09/22/915630892/in-u-n-speech- trump-blasts-china-and-who-blaming-them-forspread-of-covid-19. Accessed 24 July 2021.

[9] Allison, Graham T. Destined for War : Can America and China Escape Thucydides's Trap? Boston, Houghton Mifflin Harcourt, 30 May 2017.

[10] A.F.K. Organski. World Politics. 2nd ed., New York, Alfred A. Knopf, 1 Jan. 1968.

[11] Mearsheimer, John J. "The Gathering Storm: China's Challenge to US Power in Asia." The Chinese Journal of International Politics, vol. 3, no. 4, 1 Dec. 2010, pp. 381-396, 10.1093/cjip/poq016.

[12] National Security Council. "United States Strategic Approach to the People's Republic of China." White House, $20 \quad$ May 2020, https://trumpwhitehouse.archives.gov/wpcontent/uploads/2020/05/U.S.-Strategic-Approachto-The-Peoples-Republic-of-China-Report5.24v1.pdf. Accessed 26 July 2021.

[13] Griffiths, James, and Nectar Gan. "China Is Using Its Authoritarian Arsenal to Crack down on Anyone Who Might Spread the Wuhan Virus." CNN, 11 Feb. 2020, edition.cnn.com/2020/02/10/asia/chinasecurity-police-wuhan-virus-intl-hnk/index.html. Accessed 26 July 2021.

[14] Xinhua News Agency Reporter. "Ministry of Foreign Affairs: U.S. Response to the Pandemic Is Both Puzzling and Thought-Provoking." www.gov.cn, $30 \quad$ June 2020 , www.gov.cn/xinwen/202006/30/content_5522728.htm. Accessed 15 July 2021.

[15] Rogers, Katie, et al. "Trump Defends Using 'Chinese Virus' Label, Ignoring Growing Criticism." The New York Times, 18 Mar. 2020, www.nytimes.com/2020/03/18/us/politics/chinavirus.html. Accessed 15 July 2021.

[16] @JiayangFan. "Went to take out trash. Was talking on phone in Chinese. Man walked by on sidewalk." Twitter, 18 March 2020, 11:01 am, https://twitter.com/JiayangFan/status/12401110335 50766080 . 